\title{
The Effect of "PLANS" Training Towards Career Maturity of Senior High School Students
}

\author{
Muhammad Hidayat \\ Faculty of Psychology Universitas Ahmad Dahlan \\ muhammad.hidayat@psy.uad.ac.id \\ Asmadi Alsa \\ Faculty of Psychology Universitas Gadjah Mada \\ asmalsa@ugm.ac.id
}

\begin{abstract}
Career maturity is defined as the maturity in terms of career decision making, reflected through individual attitudes and competencies. Preliminary studies showed that many $12^{\text {th }}$ grade students found difficulties in selecting their university majors. This suggests that many $12^{\text {th }}$ grade students still lacks career maturity. PLANS training was given to $\mathrm{II}^{\text {th }}$ grade students of $\mathrm{N}$ tutoring agency with the goal of improving their career maturity. We hypothesize that PLANS training will increase the career maturity of these students. The experiment used an Untreated Control Group Design with Dependent Pretest and Posttest Samples. In this study, the independent variable is PLANS training, while the dependent variable is career maturity. Thirty students, divided equally into experimental and control group, were involved as participants. The instruments include attitude and competence career maturity scale. ANOVA analysis finding shows a significant change of career maturity scores from pretest to posttest scores in the experimental group. Meanwhile, no significant change was detected from the control group. The contribution of this training is equal to $40.4 \%$ in the attitude domain and $62.5 \%$ in the competence domain. Our findings show that "PLANS" training can significantly improve the career maturity of high school students.
\end{abstract}

Keywords: career decision making, career maturity, PLANS training,

Received 25 April 2018/Accepted 25 July 2018 @ JEHCP All rights reserved

\section{Introduction}

Senior High School (SMA) is one of the stages of formal education in Indonesia. At this period, students are in their adolescence phase, a transitional developmental period from childhood to adulthood that include biological, cognitive, and socio-emotional changes (Santrock, 2007). Adolescents have several developmental tasks that prepare them to meet the demands and 
roles as adults (Santrock, 2002). In addition, adolescents can also be regarded as the time for picking. This is particularly true with regard to career; choosing and preparing to run a job (Santrock, 2003 \& Sukadji, 2000). In this case, adolescents also have entered the stage of making career decisions (Bardick, Bernes, Magnusson \& Witko, 2006; Creed, Patton, \& Prideaux, 2006). Therefore, high school students need to firstly prepare their career by determining their college majors.

The orientation of the type of work in the future will be an important factor affecting the interests and needs of youth who will undergo education (Desmita, 2005). So, for high school students, determine the educational program, faculty and majors in college are primary or beginning of their career world (Sukadji, 2000).

During adolescence, career development goes hand in hand with age and experience, an important dynamic in the high school years. High school students begins to make plans by career exploration and searching for career-related information that suits their interest (Bardick et al., 2006). Super (in Seligman, 1994) said career development during high school begins at the age of 15 to 24 years. At this stage, adolescents develop an awareness of themselves and the world, start to try new roles, and narrow down career choices. Therefore, adolescents need career maturity.

Not all adolescents are able to easily make career decisions. Most of them experience confusion before finally making a choice (Creed et al., 2006). Memorandum and Soresi (2003) revealed that the confusion of choosing a career has become an issue in high school education. Career decision-making process often becomes a pressure for students. Anxiety and stress reaction causes students to delay career decision-making or leaves it to other parties (i.e. parents) to make a less than ideal decision on their behalf (Germeijs \& Verschueren, 2006; Keller \& Whiston, 2008; Witko, Bernes, Magnusson, \& Bardick, 2005). Survey by Syahraini (20II) in $\mathrm{II}^{\text {th }}$ grade students in Yogyakarta, showed that $59.76 \%$ of the students have difficulty choosing college majors. In addition, as many as $22.24 \%$ of students are unsure of the college majors that they have chosen. 
Based on preliminary studies conducted in $\mathrm{N}$ tutoring agency, it is concluded that many high school students, particularly $12^{\text {th }}$ grade students, lacks career maturity in choosing college majors. Career maturity problems include: (a) having no information about majors in college, (b) struggling to determine the courses relevant to their interests, (c) still having confusion on whether to continue to Higher Education, (d) not being convinced with their current choice, (e) has not made plans on majoring choice. It is associated with variations in the readiness of students in career choice, from those who are still exploring their career options to those with clear definite career goals (Argyropoulou, Sidiropoulou-Dimakakao \& Besevegis, 2007; Hirschi \& Lage, 2007). Such findings indicate that career development task have not been fulfilled, namely that adolescents should have entered the stage in which they have made definite career choice based on their career exploration (Super, in Brown \& Associates, 2002).

Career maturity problems of high school students in can be viewed from a social cognitive perspective. According to Bandura (1986), the formation of individual behavior is described in the form of mutual interaction between individual determinants (e.g. cognitive, personal factors), behavior, and environmental factors, known as the triadic reciprocity. In terms of career maturity, career decision-making (selection of study programs) is influenced by individual determinants (personal factors) and environmental factors. Fundamentally, career is a part of life that affects happiness. The career success or failure of an individual can measure a person's success in life. Therefore, accuracy in selecting and making career choices is an important point in the course of human life (Germeijs \& Verschueren, 2007).

Crites (1974) revealed that career maturity is the level of individual readiness, comprising of their attitudes and competencies in making career decision from the exploration to the declining stage of a career. Choosing and planning the right career requires career maturity that includes knowledge of self, knowledge of the job, the ability to select a job, and the ability to plan the steps towards the expected career (Crites, 1974). Herr and Cramer (1984) suggested that the concept of career maturity is used to indicate the level of career development, which is achieved by the individual stages of the exploration stage to the stage of decline. Subsequently, Brooks (1990) revealed that career maturity is the readiness of an individual, including both cognitive and affective aspects, to address the developmental tasks that he or she must 
confront. This might be due to biological and social development as well as people's expectations from the community who have reached the stage of development. The concept of career maturity by Crites (1974) which includes the attitudes and competencies in career decision making is still considered relevant (Hasan, 2006).

Crites (1974) suggested two dimensions in career maturity, namely attitude (affective) and competence (cognitive) career choice. Affective dimension consists of five aspects, namely involvement in decision-making, orientation toward work, the necessary concepts in decision making, independence in decision making, and liking for the kinds of jobs. Cognitive dimension consists of five aspects, namely problem solving, planning, employment information, selfassessment and goal choice.

Partino (2005) stated that $12^{\text {th }}$ grade students will are considered to have career maturity when they can independently choose majors based on their abilities, talents, interests and available opportunities. Additionally, they are also ready to choose further education, both formal and non-formal, or enter the work force with no further education. Career readiness is shown by the level of compatibility between various factors, such as family economic background, educational aspirations further, personal characteristics, employment opportunities and job requirements. The characteristics of high school students with career maturity are those with (Partino, 2005): (a) relatively consistent career choice, (b) a more realistic career choice, (c) a capability to make right career choices, and (d) a positive attitude in career choice. Low career maturity can lead to errors in making career decisions, including errors in determining the direction of education for high school students.

Some sources mentioned that there has been many intervention with regard to career. Intervention model varies, including: individual career counseling (Sangganjanavanich \& Magnuson, 20II), career counseling group (Austin, Wagner, \& Dahl, 2004; Lestari, 2010), a model portfolio (Dowd, 2010), the club's career by using the individual assignment (Wessel, Christian \& Hoff, 2003), interviews (Amundson, Borgen, laquinita, Butterfield, \& Koert, 2010; Kuijpers \& Scheerens, 2006), classroom course (Fouad, Cotter, \& Kantamneni, 2009; Reese \& Miller, 2006; Scoot \& Ciani, 2008), workshop (Hirschi \& Lage, 2007), and intervention training 
model (Hoelscher, Hayward, Ertl, \& Goddet, 2008; Jepsen, Dustin, \& Miars, 1992; Krumboltz \& Hamel, 2000; Kustanani, 20I0; Mulyana, 2009; Notta \& Soresi, 2003; Wang, Zhang, \& Shao, 2010). These programs proved to have positive effect in planning, selecting, and determining career (Brown \& McPartland, 2005; Whitson \& Buck, 2008).

Intervention in the form of group training was considered fairly effective in improving the career maturity in students. The training process allows participants to feel positive experience; identify and explore their capabilities; plan; construct rational knowledge about career options; and learn to take career decisions (Hoelscher, Hayward, Ertl, \& Goddet, 2008; Krumboltz \& Hamel, 2000; Teuscher, 2002; Wang, Zhang, \& Shao, 2010).

The design of this training was based on the social cognitive perspective expressed by Bandura (1986). In this perspective, the establishment of individual behavior is depicted in the form of reciprocal interaction between continuous individual determinants (e.g. cognitive and other personal factors), behavior, and environment, known as the triadic reciprocity. Crites (1974) suggested two dimensions of career maturity, namely attitudes (affective) and competence (cognitive) career choice. Affective dimension consists of five aspects: involvement in decision making, orientation toward work, the necessary concepts in decision making, independence in decision making, and liking for the kinds of jobs. Cognitive dimension consists of five aspects, namely problem solving, planning, employment information, self-assessment and goal choice.

Based on the explanation above, the environmental factors are also important to stimulate support for career maturity. Thus, if it is associated with the social cognitive theory, an increase in career maturity should be influenced by the person (cognitive and affective) that serves to analyze and make decision. The environment will then provide a stimulus that serves to support the exploration of a wide range of needed information. Next, behavior that reflect career maturity will form.

The training module preparation was done following the theory of career planning of Jaffe and Scott (Kummerow, 1991). The theory outlined five important aspects in making a career plan: self-assessment, exploring opportunities, developing career plans, taking action, and evaluating 
results. Based on this theory, five main sessions of training were drafted, namely (I) self-analysis (2) career insights, (3) goal setting and career planning, (4) a plan of action, (5) evaluation. This training was called "PLANS", an acronym of Perencanaan Lanjut Studi [Advanced Study Planning]. Figure I shows the research framework.

\begin{tabular}{|l|l|l|}
$\begin{array}{l}\text { High School } \\
\text { Students" } \\
\text { Problems: } \\
\text { Low Career } \\
\text { Maturity of } \\
\text { High School } \\
\text { Students }\end{array}$ & $\begin{array}{l}\text { Intervention: "PLANS" Training } \\
\text { Consists of 5 main sessions } \\
\text { 1. Self-analysis } \\
\text { 2. Career insights } \\
\text { 3. Goal setting and career planning } \\
\text { 4. Plan of action } \\
\text { 5. Evaluation }\end{array}$ \\
\end{tabular}

Figure I. Research Framework

This study aims to determine the effect of "PLANS" training in enhancing the career maturity of students from $\mathrm{N}$ tutoring agency, class $\mathrm{XI}$. This agency was selected as the test site because our preliminary study have found lower career maturity problems in students of that agency. Additionally, characteristic variations of those students $\mathrm{N}$ are vast, because they come from both high- and low- ranked schools. Thus, researchers compiled intervention module will be tested on a group of participants are varied, not only from one school only.

With this research, issues regarding the career of $\mathrm{II}^{\text {th }}$ grade students in $\mathrm{N}$ tutoring agency $\mathrm{N}$ can be resolved. Furthermore, career plan training module can be used to enhance the career maturity in Class XI in particular and high school students in general, both in tutorial $\mathrm{N}$ and widely studied for other students who experience similar issues.

This research can be practically useful for high school students to increase the their career maturity. Furthermore, if proven to improve the career maturity, teachers in $\mathrm{N}$ tutoring agency could use the career plan training module to help students find the most suitable career choices. We hypothesize that "PLANS" training can improve the career maturity of $\mathrm{II}^{\text {th }}$ grade students of $\mathrm{N}$ tutoring agency. 


\section{Method}

Identification of Research Variables

The independent variable of this study is the "PLANS" training. It composed of career plan training through social cognitive approach. Career planning is the process of determining future individual career plan. The training consists of five sessions: (I) self-analysis, (2) career insights, (3) goal setting and career planning, (4) a plan of action, and (5) evaluation.

The dependent variable is career maturity. Career maturity is the readiness level of an individual that includes attitudes and competencies in career decision making. Career referred to in this study is the higher education after completing senior high schools, particularly in terms of the study program or major that they want.

\section{Subjects}

The subjects are $\mathrm{II}^{\text {th }}$ grade senior high school students who register at $\mathrm{N}$ tutoring agency at $\mathrm{X}$ branch. The sample selection was selected based on these inclusive criteria are both male and female are included, twelve grade students with science majors, students with career maturity scores in the low or moderate category.

As many as 30 students (I 5 students as the experimental group and I5 students as a control group) were included in this study. Sample selection was determined by screening all $\mathrm{II}^{\text {th }}$ grade student from $\mathrm{N}$ tutoring agency (branch $\mathrm{X}$ ) to create a career maturity inventory. The screening result will inform us of the career maturity score of each student.

\section{Instruments}

The career maturity inventory was based on the theory proposed by Crites (1974). Crites suggested two dimensions of career maturity: attitudes (affective) and competence (cognitive) career choice. Affective dimension consists of five aspects, namely involvement in decision making, orientation toward work, the necessary concepts in decision making, independence in decision making, and liking for the kinds of jobs. Cognitive dimension consists of five aspects, which are problem solving, planning, employment information, self-assessment, and goal choice. Career maturity inventory consists of an attitude scale and competence tests that have been developed and tested. The attitude scale amounted to 17 items with a Cronbach's alpha value 
of 0.854 . Meanwhile, the career maturity competency that consist of 26 items had a Cronbach's alpha value of 0.890

\section{Research Design}

The study was implemented using a quasi experimental design, namely the untreated control group design with dependent pre-test and post-test samples. Measurements were carried out which provide pre-test and post-test using the same instrument (Shadish, Cook, \& Campbell, 2002). Experimental design can be seen in Figure 2.

The control group will follow the same procedure with the measurement of the experimental group without the treatment administration. With ethical considerations, the control group will be given preferential treatment after the study is completed. It was named after the waiting list group. The finding will show whether there is any difference of career decision-making scores before and after treatment. With the pre-test and the comparison group, allowing examination of specific threats to validity will become easier (Shadish, Cook, \& Campbell, 2002).

\section{Intervention}

Intervention programs are given in the form of career planning training called "PLANS". This training is designed to stimulate the participants to actively and enthusiastically participate in the training sessions to allow them to feel more confident with their career choice. This training is designed to assist individuals in improving the their career maturity.

Training module preparation, referred to as the theory of career planning, was based on Jaffe and Scott (in Kummerow, 1991). Their theory outlined five important aspects in making a career plan: self-assessment, exploring opportunities, developing career plans, taking action, and evaluating results. Based on this theory, five main training sessions were drafted: (I) self-analysis (2) career insights, (3) goal setting and career planning, (4) a plan of action, (5) evaluation. The training modules are arranged in two meetings consisting of two sessions on the first day and three sessions on the second day. In total, it will effectively take II hours for the overall 
training. The methods used in the training are individual tasks, group tasks, discussions, games, watching videos and lectures.

The module is tested prior to the validity of the content using rational analysis and professional judgment (Supratiknya, 20I I). Further, modules were also tested to see the effectiveness of the duration and procedures prior to use.

\section{Result}

Table I presents the descriptive statistics from both the attitude and competence scale of the experimental and control group, pre- and post-test.

Table I

Descriptive Statistic Data $(N=30)$

\begin{tabular}{llccc}
\hline & & Attitude Scale & \\
\cline { 2 - 5 } & Group & Mean & $\begin{array}{l}\text { Deviation } \\
\text { Standard }\end{array}$ & $\mathrm{N}$ \\
\hline Pre & Control group & 66.13 & 4.580 & 15 \\
& Experimental group & 67.40 & 4.222 & 15 \\
& Total & 66.77 & 4.376 & 30 \\
\cline { 2 - 5 } Post & Control group & 64.13 & 4.454 & 15 \\
& Experimental group & 73.93 & 6.787 & 15 \\
& Total & 69.03 & 7.527 & 30 \\
\hline \multirow{4}{*}{ Pre } & Competence Test & $\mathrm{N}$ \\
& Group & Mean & Deviation & 15 \\
& Experimental group & 19.60 & 2.585 & 15 \\
& Total & 18.20 & 2.426 & 30 \\
\hline Post & Control group & 18.90 & 2.564 & 15 \\
& Experimental group & 21.73 & 2.354 & 15 \\
& Total & 20.56 & 2.416 & 30 \\
\hline
\end{tabular}

Based on Table I, the mean pre-test and post-test when experiencing both the scale difference in the attitude and competency tests. Pre-test mean attitude scale in the control group was 66.13 and the mean post-test scores decreased to 64.13. Meanwhile, the experimental group had a pre-test mean was 67.40 and the mean for the post-test increased to 73.93. Furthermore, 
the mean pre-test to test competence in the control group was 19.60 and the post-test mean score decreased to 19.40. Meanwhile, in the experimental group, the pre-test mean is 18.20 and the mean post-test increased to 21.73 .

\section{Hypothesis Testing}

The hypothesis is PLANS training can improve the career maturity of high school students in the experimental group than the control group. Before testing the research hypothesis, we performed homogeneity tests to determine whether the covariance scores between the two groups are homogeneous. Based on the analysis, the Box's test of significance was 0.324 ( $>$ > $0.05)$ on the attitudes scale and 0.465 ( $p>0.05)$ on the competence scale. These results show that the career maturity covariance score for both attitude and competence are homogeneous. Hypothesis testing is done with mixed ANOVA with a saw table test of within-subject effects. Summary of hypotheses related data are presented in Table 2.

Table 2

Hypothesis Testing Within-subject Effect on Career Maturity

\begin{tabular}{|c|c|c|c|c|c|}
\hline \multicolumn{6}{|c|}{ Attitude Scale } \\
\hline Sources & $\begin{array}{l}\text { Type III Sum of } \\
\text { Square }\end{array}$ & $d f$ & $\begin{array}{l}\text { Mean } \\
\text { Square }\end{array}$ & $F$ & Sig \\
\hline Time & 154.133 & I & 154.133 & 4.573 & .041 \\
\hline Time*group & 546.133 & I & 546.133 & 16.203 & .000 \\
\hline $\begin{array}{l}\text { Error } \\
\text { (time) }\end{array}$ & 943.733 & 28 & 33.705 & & \\
\hline \multicolumn{6}{|c|}{ Competence Test } \\
\hline Sources & $\begin{array}{l}\text { Type III Sum of } \\
\text { Square }\end{array}$ & $d f$ & $\begin{array}{l}\text { Mean } \\
\text { Square }\end{array}$ & $F$ & Sig \\
\hline Time & 83.333 & I & 83.333 & 20.809 & .000 \\
\hline Time*group & 104.533 & I & 104.533 & 26.102 & .000 \\
\hline $\begin{array}{l}\text { Error } \\
\text { (time) }\end{array}$ & 112.133 & 28 & 4.005 & & \\
\hline
\end{tabular}

In Table 2 line time*group, it is known that $F=16.203$ for the attitude scale with $P=0.000$ ( $P$ $<0.0 I)$ and $F=26102$ for the competency test with $P=0.000(P<0.0 I)$. This suggests there is 
an interaction between time (pre-test and post-test) in both groups (experimental and control). The interaction indicates that the change in both attitude and competence scores career maturity from pre-test to post-test in both groups (control and experimental) is significantly different.

The research hypothesis is accepted, where the career maturity of the experimental group was higher than the control group. The effective contribution of training can be seen from the partial eta square value of 0.404 and an attitude scale competency test for 0,625 . These results can be interpreted that the training "PLANS" given to high school students can improve the attitude of career maturity of $40.4 \%$ and competence of career maturity of $62.5 \%$. The control group did not significantly contribute effectively to the career maturity.

\section{Additional Analysis}

The additional analysis serves as a manipulation check. The goal is to see the scores of knowledge before and after the treatment.

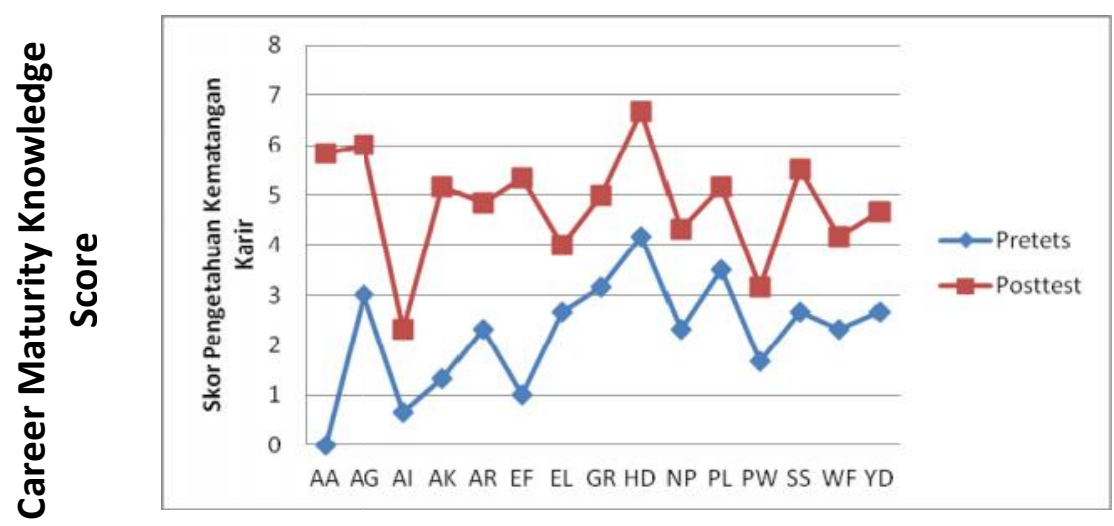

Figure 3. Pre and Post-Treatment Knowledge Score

Pre-test and post-test scores were analyzed using the Wilcoxon Signed Rank Test. Based on the analysis of the knowledge of decision-making on the trainees, all showed greater post-test scores than pre-test scores which asymp value. Sig $=0.00 \mathrm{I}(\mathrm{p}<0.0 \mathrm{I})$ means that there is a significant increase in knowledge of decision-making scores of participants after training. 


\section{Table 3.}

Differences of Knowledge Score from Pre-test to Post-test

\begin{tabular}{ll}
\hline Test Statistics & Post-test - Pre-test \\
\hline Z & $-3.408^{\mathrm{a}}$ \\
Asymp. Sig. (2-tailed) & .001 \\
\hline
\end{tabular}

\section{Discussion}

This study aims to look at the effect of "PLANS" training to the career maturity of high school students. The experiment used an untreated control group design with dependent pre-test and post-test design. The analysis showed $F=16,203(p<0.01)$ for the attitude scale and $F=26,102$ $(p<0.01)$ for the competence test. This suggests that there is an interaction between time (pretest and post-test) in both groups (experimental and control). The interaction indicates that the change in both attitude and competence career maturity scores from pre-test to post-test in both groups (control and experimental) is significantly different.

Based on our finding, "PLANS" training can improve the career maturity of high school students. In other words, the hypothesis is accepted. Career maturity may include two dimensions: attitudes/affective and competence/cognitive (Crites, 1974). Attitude dimensions were measured using an attitude scale, while competence is measured by competency tests that have previously been tested. Before being given treatment, participants were given the experimental manipulation check to determine the extent of their knowledge on the materials provided. Furthermore, participants were given a sheet of reflective journals to see the extent to which an increase in their knowledge. The results show that participants in the experimental group experienced a significant increase in knowledge on career planning.

The "PLANS" training assisted participants in identifying their interest and capability themselves. Participants were also facilitated to analyze the fit between potential-interest with a chance of 
that course by considering the supporting and inhibiting factors. The process is guided by a group discussion with co-trainers who trained individuals to make career choices and career planning. Of these dynamics, it is evident that the training enhances career maturity of the participants.

Based on the evaluation sheet, it appears that all participants found "PLANS" training to be beneficial. After receiving training, participants became more confident in their choice of college majors, attain adequate information about university courses, and became more focused following their career planning. One of the participants, SS, stated that he gained better understanding of his potential and interest, became more aware of the information department at the university and more focused after receiving the training. This shows an increase in career maturity on both the attitude and cognitive dimension of the participants. The increase in career maturity after the "PLANS" training enabled participants to determine the direction they will take in college. One of the participants, PW, said that before the training he was still very much undecided on the majors that he would like to take. However, after "PLANS", he set a steady course objectives, namely Mathematics Education.

The success of "PLANS" in improving career maturity within the experimental group is supported by the theory of career planning by Jaffe and Scott. According to Kusumaningrum (2012) and Ardiyanti (2014), these career guidance workshops and career planning trainings have been proven to increase self-efficacy in career decision-making of high school students. All training sessions are based on the career planning stages of Jaffe and Scott (in Kummerow, 1991), which assesses self, explores opportunities, develops career plans, takes action, and conducts evaluation. The name "PLANS" itself is taken from the acronym of "Perencanaan Lanjut Studi" [Advanced Planning Study]. The compiled module can assist students to make planning in his studies in higher education in accordance with his/her passion.

The "PLANS" module was constructed based on Bandura's theory, namely Observational Learning. This theory has been shown to significantly increase the career maturity of the experimental subject group. This increase can be seen from mean difference between pre-test and post-test of both the attitude scale $(M D=-3.533)$ and competence scale (MD = -6.533). 
This increase proves the effectiveness of applying observational learning as a means to learn new skills (Bandura, 1986). Observational learning, the process has four stages, namely: I) Attention, 2) Retention, 3) Production, and 4) Motivation (Bandura, 1986). The module is based on the process of observational learning. In the attention phase, the trainer explained career planning materials, stages in career planning, case examples of students who chose the wrong majors, and video playback. This process is done to equip subjects with the necessary knowledge. This is in line with Gati, Krausz, \& Osipow (1996) who stated that, to be effective in making career decisions, individuals must have information about self-analysis, chose a career environment, and integrate them as a basis for career decision-making process.

In the retention phase, trainers review how much has been understood by the subjects. They will ask subjects to explain the materials that they have studied to each other according to his or her understanding. The use of individual reflective journals on each session is used to strengthen their understanding of the materials. On that journal, subjects can write what knowledge they have learned from the trainers and facilitators.

The production stage is done through small group discussion guided by a facilitator who will also ask the participants to complete a career planning worksheet. During this stage, participant will practice to apply new knowledge and skills to the worksheet. The fourth stage is the motivational stage. At this stage, the participants will be asked to present the worksheets that they have completed. Trainers and facilitators provide reinforcement to the presentation to ensure that participants gained better understanding of how the training have benefit them. Trainers also provide rewards and positive feedback to motivate the participants.

All participants were present during the planning stages of their career. They were then asked to elaborate on their analysis, career insight, goal setting process and career planning as well as a plan of action and evaluation. This was conducted with the aim of helping the subjects clarify the direction of their education to a higher level.

"PLANS" training can effectively improve career maturity, because the modules were constructed based on the analysis of existing student problems. In addition, the training module 
was developed based on observational learning theory (Bandura, 1986) which has been known to be effective for improving knowledge and skills. Training modules were reviewed through professional judgment prior to being used for data collection. It was also tested to ensure that we have a technically ideal field conditions.

Overall, taking into consideration the steps taken during training, the "PLANS" module is proven to improve career maturity. This increase is not only seen from the increase in scale scores, but also from the reflective journals filled out by each subject. The average respond within the reflective journals of the subjects have conveyed the purpose desired by the researcher.

Trainers and facilitators are role models that participants can imitate to learn new skills. Small group discussion as part of the training evaluation shows that participants favored the training because it allows them to explore more about the self-analysis and career insight. This is consistent with Bandura (1986) who viewed a success process of attention as the interaction between the model and observer. The model has an appeal that allowed observer to truly pay attention to what is conveyed by the model.

At the end of the session, the entire participants were able to present their career plan. Each participant presented about their analysis, selected majors, action plans and evaluation. They also felt that the training was beneficial for them. Providing motivation by giving praise to the subject helps to maintain the subject's behavior.

This study is not free from limitation. Limitation of this study is the lack of follow-up data after the post-test. Thus, we could only determine the short-term effect of "PLANS" training. Follow-up data is critical in determining whether the long-term effect of the intervention can be sustained. This is because a problem cannot be considered solved if the improvement does not last (Martin \& Pear, 2003). Additionally, both subjects from the control and experimental groups, already have high early career maturity scores. However, this training can significantly increase career maturity scores in effectiveness, though donations are not too big that only $40.4 \%$ to $62.5 \%$ attitude and dimension to the cognitive dimension. 


\section{Conclusion}

The results show that "PLANS" training can significantly improve the career maturity of high school students. Subjects reported gaining more knowledge about self-analysis, information on Higher Education, and drive to make plans to study in college after the completion of the experiment. Future research are advised to: (I) conduct an experimental design with follow-up data to determine the long-term effect of this training; (2) select participants in accordance to the predetermined inclusion criteria, ensuring appropriate treatment are administered to subjects that are considered as the target.

\section{Acknowledgement}

I would like to thank Prof. Dr. Tina Afiatin, SU, lecturer of the Faculty of Psychology, Universitas Gadjah Mada for her contribution in this study as an expert judgment of the training module.

\section{References}

Amundson, N.E., Borgen, W.A., laquinta, M., Butterfield, L.D., \& Koert, E. (2010). Career decision from the decider's perspective. The Career Development Quarterly, 58, 336-35I.

Argyropoulou, E.P., Sidiropoulou - Dimakakou, D., \& Besevegis, E.G. (2007). Generalized selfefficacy, coping, career indecision, and vocational choice of senior high school students in greece: implication for career guidance practitioners. Journal of Career Development, 33 (4), 316-337.

Austin, R.K., Wegner, B. \& Dahl, D. (2004). Reducing career indeciveness in adults. International Journal of Disability Community and Rehabilitation, 3(2), 42-65.

Bardick, A. D. Bernes, K. B., Magnusson, K. C., \& Witko, K. D. (2006). Junior high school student's plans for the future. Journal of Career Development, 32, 250-27I.

Bandura, A. (1986). Social Foundations of Thought and Action: A Social Cognitive Theory. New Jersey : Prentice-Hall

Brooks, L. (1990). Recent developments in theory building. In D. Brown and L. Brooks (Eds.), Career choice and development: Applying contemporary theories to practice (2nd ed). San Francisco: Jossey-Bass. 
Brown, D., \& Associates (2002). Career choice and development (4 $4^{\text {th }}$. Ed.). San Francisco: JosseyBass.

Creed, P., Patton, W., \& Prideaux, L. A. (2006). Causal relationship between career indecision and career decision making self efficacy. Journal of Career Development, 33, I, 47-65.

Crites, J.O. (1974). The career maturity inventory. New-york: McGraw-Hill Book Company.

Desmita. (2005). Psikologi perkembangan. Bandung: Remaja Rosda Karya.

Dowd, L. (2010). The Career priorities profile (2nd. Ed). Diakses pada tanggal 4 Desember 2013 dari http://www.career-lifeskills.com/pdf/jst-577896_guide.pdf

Fouad, N., Cotter, E.W., \& Kantamneni, N. (2009). The effectiveness of a career decisionmaking course. Journal of Career Assesment, I 7, 338-347.

Germeijs, V., \& Verschueren, K,. \& Soenens, B. (2006). Indeciveness and High school students career decision-making process: Longitudinal association and the meditational role of anxiety. Journal of Counseling Psychology, 53(4), 397-4I0.

Hasan, B. (2006). Career maturity of indian adolescents as a function of self-concept, vocational aspiration and gender. Journal of the Indian Academy of Applied Psychology, $32(2)$, $127-134$.

Herr, E. L., \& Cramer, S. H., (1979). Career guidance through the life span. Systematic approaches. Boston : Little, Brown \& Company

Hirschi, A., \& Lage, D. (2007). The relation of Secondary students career choice readiness to a six-phase model of career decision-making. Journal of Career Development, 34(2), 164191.

Hoelscher, M., Hayward, G., Ertl, H., \& Goddet, H. D. (2008). The transition from: Vocational education and training to higher education; a successsful pathway. Research Paper in Education, 23(2), |39-I5I.

Jepsen, D. A., Dustin, R., \& Miars, R. (1992). The effect of problem-solving training on adolescent'career exploration and career decision making. The Personal and Guidance Journal, 5, I49-153

Keller, B. K., \& Whiston, S. C. (2008). The role of parental influences on young adolescents's career development. Journal of Career Assessment, 16, 198-217.

Krumboltz, J.D., \& Hamel, D.A. (2000). The effect of decision training career decision making competence. Research Institute of the Behavioral and Social Sciences. Stanford University, California. 
Kummerow, J. M. (199I). New Direction in Career Planning. California: CPP Book

Kustanani, E.R. (20I0). Efektifitas pelatihan "lebih dekat dengan masa depanku” untuk menggapai kematangan vokasional siswa SMP. Tesis (Tidak diterbitkan). Fakultas Psikologi Universitas Gadjah Mada.

Kusumaningrum, D. S. (2012). Pengaruh workshop bimbingan karir terhadap efikasi diri dalam pengambilan keputusan karir. Tesis (tidak dipublikasikan). Yogyakarta: Fakultas Psikologi Universitas Gadjah Mada.

Lestari, R.T. (2010). Peran konseling karir "bersama menggapai cita" dalam meningkatkan keterampilan penetapan keputusan karir pada siswa perempuan SMA. Tesis (tidak diterbitkan). Fakultas Psikologi: Universitas Gadjah Mada.

Mulyana, O. P. (2009). Peningkatan efikasi diri terhadap pengambilan keputusan karir melalui pelatihan perencanaan karir. Tesis (tidak diterbitkan). Yogyakarta: Fakultas Psikologi Universitas Gadjah Mada.

Nota, L. \& Soresi, S. (2003). An assertiveness traning program for indecisive students attending an Italian University. The Career Development Quarterly, 5, 322-343.

Osipow, S.H. ( 1983). Theories of career development. Englewood Cliffs, New Jersey: Prenrice-Hall Inc.

Partino, H.R. (2005). Kematangan karir siswa SMA Jayapura Provinsi Papua. Disertasi (Tidak diterbitkan). Yogyakarta: Fakultas Psikologi Universitas Gadjah mada.

Pietrofesa, J.J., \& Splete, H. (1975). Career development: Theory and research. New York: Grune and Stratton.

Reese, R.J. \& Miller, C.D. (2006). Effects of a university career development course on career decision making self efficacy. Journal of Career Assesment, I4(2), 252-266.

Sangganjanavanich, V.F., \& Magnuson, S. (20II). Effective, techniques using sand trays and miniature figures to facilitate career decision making. The Career Development Quarterly, $59,264-273$.

Santrock, J. W. (2002). Life span development: Perkembangan masa hidup. Jilid 2. Jakarta: Penerbit Erlangga.

Santrock, J.W. (2007). Perkembangan anak. Penerjemah: Rachmawati, M \& Kuswanti, A. Jakarta: Erlangga.

Scott, A.B., \& Ciani, K.D. (2008). Effect of an Undergraduate career class on Men's and Women's career decision-making self efficacy and vocational identity. Journal of Career Development, 34(3), 263-285. 
Seligman, L. (1994). Developmental career counseling \& assesment (2nd ed). California: SAGE Publications.

Shadish, W.R, Cook, T.D., Campbell, D.T. (2002). Experimental and quasi-experimental design for generalized causal inference. New York: Houghton Mifflin Company.

Sukadji, S. (2000). Psikologi pendidikan dan psikologi sekolah. Depok: LPSP3 Universitas Indonesia.

Supratiknya, A. (20II). Merancang program dan modul psikoedukasi. Universitas Sanata Dharma, Yogyakarta.

Syahraini. (20/2). Pelatihan "menemukan langkah terbaikku” untuk meningkatkan keterampilan pengambilan keputusan karir pada siswa MAN. Tesis (tidak diterbitkan). Fakultas Psikologi Universitas Gadjah Mada.

Tang, M. (2009). Examining the application of Holland's theory to vocational interest and choice of chinesse college students: Journal of Career Assesment, I 7(I), 86-98.

Teuscher, U. (2002). Evaluation of a decision training program for vocational guidance. Departement of Psychology, University of Fribourg, Switzerland.

Wang, J., Zhang, D., \& Shao, J. (2010). Group Training on the improvement of college student's career decision-making self efficacy. Center for Mental Health Education, 2(6), 55 I-556.

Wessel, R.D., Christian, N.T., \& Hoff, A.K. (2003). Enhancing Career development through the career success club. Journal of Career Development, 29(4), 265-274.

Witko, K., Bernes, K. B., Magnusson, K., \& Bardick, A. D. (2005). Senior high school career planning: What student want. Journal of Educational Inquiry, 6, 34-49. 